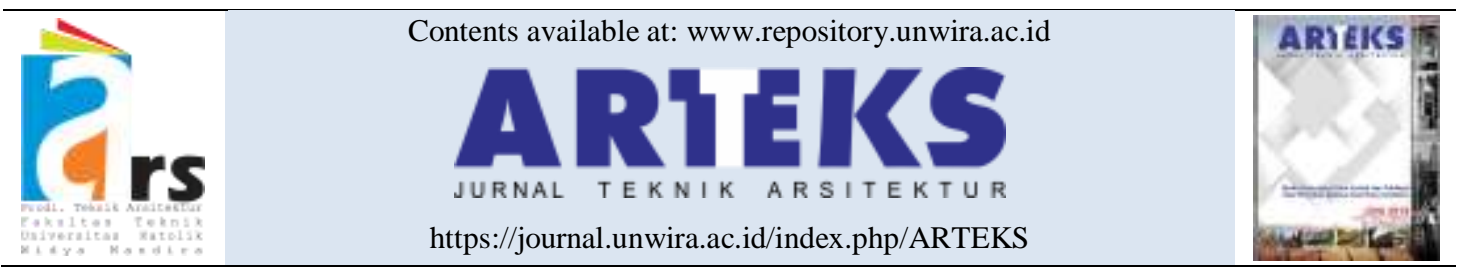

Research paper

doi: 10.30822/arteks.v6i3.1203

\title{
Infiltration optimization efforts towards sustainable land-use
}

\section{A case study of Makassar City}

\author{
Architecture Study Program, Faculty of Engineering, \\ Universitas Muhammadiyah Makassar \\ Jl. Sultan Alauddin, No. 259, Makassar, Indonesia
}

Sahabuddin Latif ${ }^{(D)}$, Nurhikmah Paddiyatu* ${ }^{*}$, Andi Yusri, Sumarni Baking

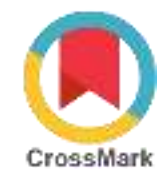

\begin{tabular}{|c|c|}
\hline ARTICLE INFO & ABSTRACT \\
\hline $\begin{array}{l}\text { Article history: } \\
\text { Received June } 30,2021 \\
\text { Received in revised form July } 05,2021 \\
\text { Accepted July } 14,2021 \\
\text { Available online December } 01,2021\end{array}$ & $\begin{array}{l}\text { The degradation of land due to conversion is a global process with } \\
\text { a significant effect on land use. The intensification of land use in } \\
\text { Makassar City is observed to have dramatically affected water } \\
\text { retention hydrology, thereby, leading to an increase in volume, } \\
\text { runoff rate, and filtration loss. Therefore, it is necessary to optimize }\end{array}$ \\
\hline $\begin{array}{l}\text { Keywords: } \\
\text { Built-up area } \\
\text { Infiltration capability } \\
\text { Inundation } \\
\text { Land-use } \\
\text { Runoff } \\
\text { *Corresponding author: Nurhikmah } \\
\text { Paddiyatu } \\
\text { Architecture Study Program, Faculty of } \\
\text { Engineering, Univesitas Muhammadiyah } \\
\text { Makassar, Indonesia } \\
\text { Email: nurhikmah@unismuh.ac.id } \\
\text { ORCID: https://orcid.org/0000-0002-0487- } \\
\text { 1773 }\end{array}$ & $\begin{array}{l}\text { infiltration by mapping the classification of infiltration capability } \\
\text { based on the land-use changes observed between } 2005 \text { and } 2020 \text { as } \\
\text { well as the inundation occurring due to surface runoff. This research } \\
\text { uses a quantitative method by calculating the run-off spatial data } \\
\text { and statistics to determine the area with low infiltration capability } \\
\text { in the built-up environment. The results showed a decrease in } \\
\text { infiltration capability of } 3.6 \% \text { which represents } 617.72 \text { ha at critical } \\
\text { levels in the built-up area in the last } 15 \text { years. This means it is } \\
\text { possible for decision-makers to implement infiltration optimization } \\
\text { steps as the alternative solution by focusing only on the land-use } \\
\text { distribution with critical initial conditions. The findings of this } \\
\text { research are expected to minimize surface runoff rate and excess } \\
\text { inundation potential in order to achieve sustainable land use in } \\
\text { Makassar City. }\end{array}$ \\
\hline
\end{tabular}

\section{Introduction}

Indonesia is currently focusing on mechanisms supporting land use and also implementing efforts to address environmental issues (Tristan Grupp 2020). These environmental problems are, however, generally caused by natural events, rapid population growth (Hasibuan et al. 2021), excessive use of natural resources, industrialization, and transportation (Manik 2016). Urban and infrastructural development is also one of the soil-sealing practices causing environmental degradation, especially land, and has the most intense effect on all ecosystem services (Artmann 2014; Tobias et al. 2018). This is associated with the activities observed to be increasing the need for space significantly when compared to the available land, thereby, leading to the massive conversion of non-built areas into built-up areas (Histanto and Kusliansjah 2018). Moreover, surface water flooding or runoff is considered the most serious problem related to land use in many big cities and areas (Rogger et al. 2017; Patanduk, Arsyad, and Rauf 2014; Sudia et al. 2018; Khare et al. 2017). The previous research conducted between 2003 - 2008 showed the land-use change in Makassar city was significant in the settlement sector which increased by 1239.75 ha $(6.99 \%)$ while the value was recorded to be 693 ha $(3.91 \%)$ between 2008 - 2013. The unaffected areas were reported to include the lakes or reservoirs and rivers while those added include settlements, cemeteries, swamps and landfills, industry and warehousing, trade, roads, and services with settlements found to have taken the highest with 693 ha. The land 
area observed to have reduced includes vacant land, ponds, and rice fields with the vacant land observed to have been most affected with a total of 818 ha. These changes in land use, therefore, have a significant impact on the runoff coefficient as indicated by the 0.48 recorded in 2003, 0.53 in 2008, and 0.56 in 2013 (Patanduk, Arsyad, and Rauf 2014). The conditions associated with changing open land to closed land were observed to have reduced the infiltration capability potential as indicated by the areas with high values having low values due to land conversion or built-up area. Furthermore, the compaction process in building construction affects soil permeability while the changes in function and a tightly closed environment was were also reported to have caused the soil to receive a much higher volume of water through runoff due to the soil landscape (Pouyat et al. 2020).

Infiltration is the movement of water from the surface to the subsurface (Gargouri-Ellouze et al. 2018). The optimization process has shown the important role of other storage aspects such as the vegetation as well as natural (rivers) and artificial (urban drainage) channels in infiltration. Moreover, urban development has been discovered to be changing natural land which is capable of conducting a hydrological cycle into watertight surface land full of construction, thereby, leading to the inability of the soil to absorb water. This, therefore, causes an increase in the volume and velocity of runoff and reduces the volume of water stored in the soil (Lazaro 1990).

Land-use is a term widely used in classifying different types of activities related to land usage (Ardhiansyah, Widyastuti, and Septiari 2019). Land-use heritage was reported to be strongly influenced by the environmental services in its previous usage and the urgency to maintain the ecosystem services or functions through several management actions (Perring et al. 2016). Moreover, each use has certain characteristics applied to determine its compatibility, location, and preference in the city. It is important to note that the plans for land use also consider both the city's physical development and social characteristics (Forth \& Van Dy 2020). However, different types of land use affect soil organic matter and cause some variations in the stability of the quantity of aggregate to water (Baskan, Dengiz, and Gunturk 2016). Some previous studies have discussed infiltration but rarely relate the concept to spatial functions as well as the impact of inundation distribution on runoff. This means land-use management is needed in this context based on the natural hydrological function of the land. Therefore, this research offers an idea of sustainable land-use management concept to overcome these problems. It is one of the longterm environmental conservation efforts related to groundwater in an urban setting and has the ability to enhance natural ecosystems while providing a more aesthetically pleasing space for people living and working in urban environments (Chan et al. 2018).

A circular flow-land-use management concept was also introduced in Europe to promote sustainability in terms of compact cities and reduction of green land use due to urban sprawl. (Preuß and Verbücheln 2013). Therefore, this research was conducted to explore the distribution of infiltration capability based on changes in land use and also to develop this concept by focusing more on ensuring effective management of degraded land. This is very important, especially for science, in relation to the sustainability of land function. The results are, therefore, intended to provide information on the land or space distribution to be optimized in relation to infiltration capability in areas with critical or low infiltration land conditions or soil-sealing. This is expected to assist in optimizing the infiltration process towards achieving environmental performance in sustainable land use. It is also projected to help in managing and recovering infiltration capability in the hydrological natural cycle to ensure its adaptation to the environment. Therefore, urban regeneration which is a process including land-use planning, construction activities, and land regulation (de-sealing) is needed (Adobati and Garda 2020). Furthermore, a protection-based policy which prioritizes environmental functions is needed in urban land management to ensure long-term stability. This led to the formulation of the research question that "how can infiltration in land conditions or soilsealing be optimized in Makassar City based on 15 years of land-use conversion covering between 2005 and 2020?"

\section{Method}

An Overview of the Research Site: The research was conducted in the administrative region of Makassar City with an area of $\pm 17,108.89 \mathrm{Ha}$ and 
astronomically located between $119^{\circ} 24^{\prime} 17^{\prime} 38^{\prime \prime}$ East Longitude and $5^{\circ} 8^{\prime} 6^{\prime} 19^{\prime \prime}$ South Latitude as indicated in figure 1 . The mainland is the focus due to its very high and massive potential for land conversion compared to the surrounding islands. Moreover, the research was conducted for eight months starting from April to December 2020 using both primary and secondary data. The primary data was the Makassar City land cover data for the last 15 years which is from 2005 to 2020 and obtained from the digitization of satellite images. In this case, the changes in land function were analyzed to review the cause for the decreasing infiltration observed in existing land conversion. Meanwhile, the secondary ones include data on rainfall or rain intensity, soil type, and slope from relevant agencies such as the Meteorology, Climatology, and Geophysics Agency, the Central Statistics Agency, and the Makassar City Spatial Planning Office.

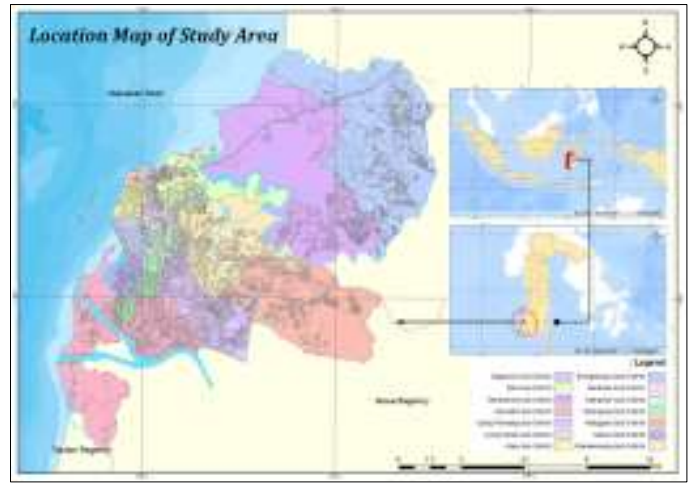

Figure 1. Village area of Samin Klopoduwur Blora Source: Processed Map of the Regional Spatial Plan (RTRW) Makassar City, 2020

Spatial analysis

One of the spatial analysis methods used in this research is the overlay process between two or more thematic layers to obtain the thematic combinations in accordance with the equation used. The map overlay is also known as a spatial analysis technique which is generally a set of methods which function when the aspect of the research object contains spatial data having features such as connected structures or patterns developed from location-based variations (Flury et al. 2021). It is important to note that spatial analysis is specifically a collection of spatial exploration techniques and statistics which help planners understand the spatial meanings contained in geographical information. Meanwhile, an overlay is one of the procedures for spatial data analysis which involves the modification of the layer according to what is needed. The process consists of several methods which include identity, intersect, union, update, erase, and symmetrical difference. This research, therefore, applied ArcGIS 10.4.1.5686 software to conduct this analysis in order to determine the changes in land use between 2005 and 2020 and also evaluate the space distribution on land with optimized infiltration capability.

Infiltration capability analysis

The infiltration capability was identified using spatial methods with several adapted and modified parameters (Sudarmanto, Buchori, and Sudarno 2013) such as flow density, rock types, land textures, and slope slopes. Moreover, each parameter was classified according to its type and provided a certain weight after which the accumulation of each weight was used to determine the infiltration capability class. However, this classification is a natural physical factor, but a comprehensive analysis requires the consideration of land-use factors as controls or determinants to understand the ability of the land to absorb the water that falls on its surface. The infiltration capability class and land-use factors were later associated and processed on the cross matrix. It is important to note that the only land optimized were those with a surface flow coefficient level above $50 \%$ or with Low Infiltration. Moreover, the critical land was determined by analyzing the inundation distribution using a runoff mechanism that converts every coefficient of land-use according to Kodoatie and Syarif, Kironoto, Haryono, Subarkah (Praseyto et al. 2013).

\section{Runoff (surface water) rate analysis}

The runoff was calculated using the data on the coefficient of runoff, rain intensity, and research area. The runoff coefficient was determined based on the identification of land cover while the rain intensity was based on the average rainfall intensity per day and the land area was the total area covered by land in Makassar City. Moreover, the runoff rate was calculated using the Rational method USSCS (1973) as follows (Arisandhy, Aysa, and Ihsan 2013) where $\mathrm{Q}=$ surface flow rate $\left(\mathrm{m}^{3} /\right.$ second $), \mathrm{C}=$ surface flow coefficient, $\mathrm{I}=$ rain intensity $(\mathrm{mm} /$ hour$)$, and $\mathrm{A}=$ Land area $\left(\mathrm{km}^{2}\right)$.

$$
\mathrm{Q}=0,278 \text {. C.I. } \mathrm{A}
$$


The runoff rate value was later used to determine the inundation/flood distribution by comparing it with the volume of the research area. This is based on the assumption that the area is flooded when the runoff rate is greater than the volume.

\section{Result and discussion}

Land-use dynamics in Makassar City

The focus of this research was on the Makassar City development based on land use in the last 15 years from 2005 to 2020 as indicated in figure 2 .

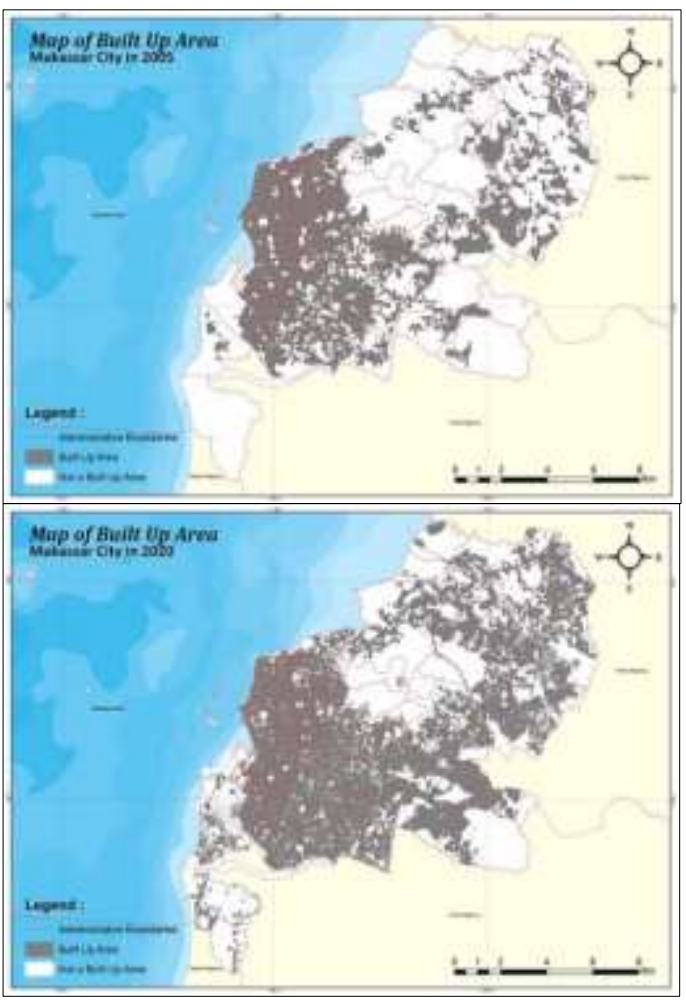

Figure 2. The development map of built-up area in the last 15 years $(2005-2020)$

Every land use was digitized and analyzed using the satellite images from 2005 and 2020 and most of the land in Makassar city was observed to have been used as a built-up area with the rapid development causing different land conversions. The results showed the land-use development has extended to the northeastern and southeastern parts of the city (Gowa Regency) due to the need for more space within the limited land. Moreover, increasing occupancy caused by the continuous increase in population and urbanization was also observed to have mostly caused the conversion of swamps, mixed gardens, vacant land, rice fields, moorings, and other open spaces into settlements or housing. This led to an $8.26 \%$ increment in the changing of open land to closed land or pavements as shown in figure 3a. Furthermore, the data processing results showed the land-use for settlements and roads dominates the built-up area in 2020 with $58 \%$ and $24 \%$ respectively as indicated in figure $3 \mathrm{~b}$. This shows massive development is associated with two land-use purposes over the last 15 years.

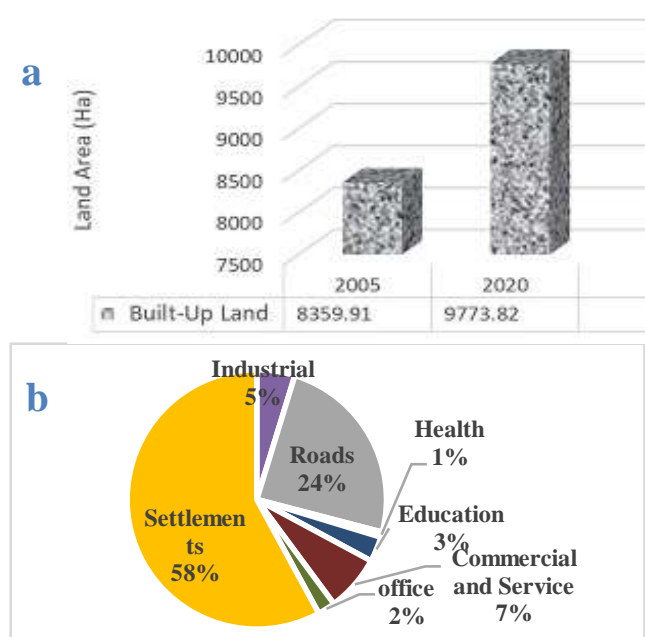

Figure 3. a. Built-up Land in 2005 and 2020; b. Percentage of Area on Land-use (built) in 2020

Critical land and infiltration capability

Critical land is degraded land whose functionality has reduced and requires optimization to reach its previous status. The function, in this case, includes the production and irrigation system. The production aspect focuses on the use of land as a source of nutrients for plants while the irrigation aspect is related to its function as a root base and groundwater storage (Praseyto et al. 2013). Degraded land also experiences minimal infiltration due to human activities and this means it needs to be optimized to regain its quality and capacity.

Infiltration is a natural ecological process which is closely related to land use with the capacity strongly influenced by the change in the usage of land in an area. This was further proven by scientific research which states that the initial and stable infiltration rate of the soil increases after the change in the land use from grassland to 
a forest (+41.35\%), shrubs to a forest (+42.73\%), and agricultural land to agroforestry $(+70.28 \%$, $+84.17 \%$ ). Moreover, soil infiltration rate was observed to have reduced after land-use changes from grasslands to agricultural land $(-45.23 \%)$, bushes to agricultural land $(-64.24 \%)$, and forests to agricultural land $(-53.58 \%, 42.15 \%)$. Soil infiltration rate is also negatively related to soil density and initial moisture but positively related to organic matter content and total soil porosity (Sun et al. 2018). Furthermore, settlement land use is highly inversely proportional to infiltration and runoff condition. This is supported by the findings of Syauqi and Dibyosaputro (2017) that the magnitude of the decrease in the rice field area and increase in dense settlements area are the causes of the reduction in the infiltration coefficient and increase in the surface runoff coefficient. This present research analyzes, classifies, and determines infiltration capability based on modified indicators (Sudarmanto, Buchori, and Sudarno 2013) such as the land-use trends with slopes, management of land with rocks, soil texture, and river flow density. The distribution map in table 1 and figure 4 shows a $3.6 \%$ decrease with 500.66 ha in land infiltration capability in 2005 with most of the decline recorded in Manggala, Tamalanrea, Biringkanaya, and Tamalate Sub-districts based on 2020 data as indicated in figure 5 .

Table 1. Classification of infiltration capability in land-use in 2005 and 2020

\begin{tabular}{|c|c|c|c|c|c|c|}
\hline Infiltration & 2020 & & & 2005 & & \\
\hline Capability & Area (ha) & $\%$ & & Area (ha) & $\%$ & \\
\hline Good & 286.09 & 1.7 & \multirow[b]{2}{*}{15.0} & 341.02 & 2.0 & \multirow{2}{*}{18.3} \\
\hline Natural normal & 2282.35 & 13.3 & & 2797.69 & 16.4 & \\
\hline Starting to become critical & 374.19 & 2.2 & 2.2 & 421.64 & 2.5 & 2.5 \\
\hline Slightly critical & 2202.78 & 12.9 & \multirow{2}{*}{82.8} & 2085.72 & 12.2 & \multirow{2}{*}{79.2} \\
\hline Critical & 11963.48 & 69.9 & & 11462.82 & 67.0 & \\
\hline Grand total & 17108.89 & 100.0 & & 17108.89 & 100.0 & \\
\hline
\end{tabular}
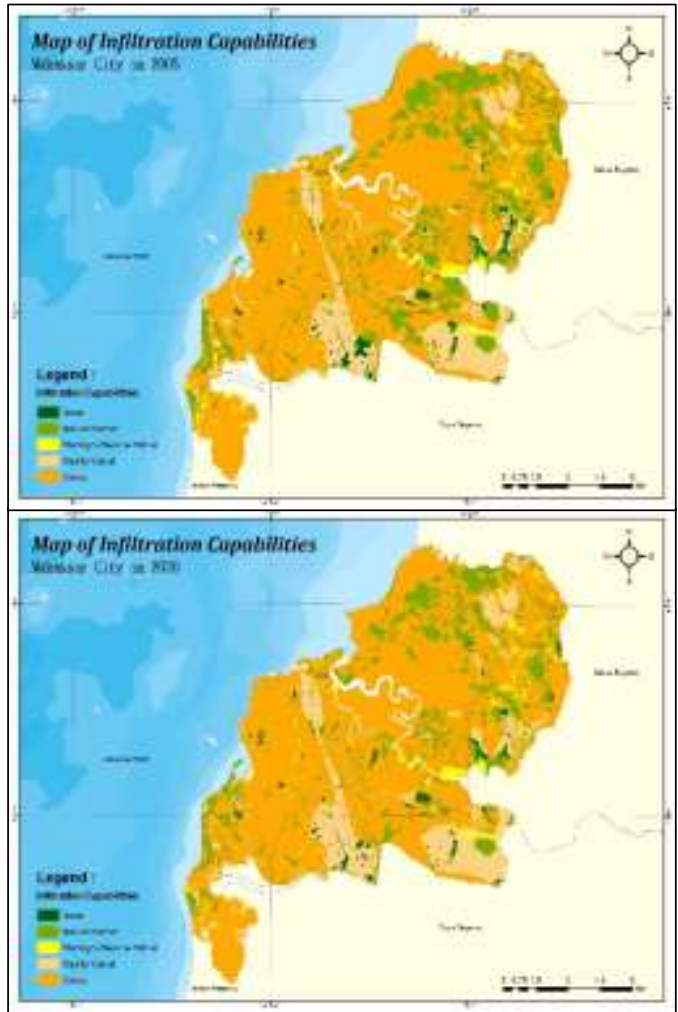

Figure 4. Distribution map for the classification of infiltration capability on land use in 2005 and 2020

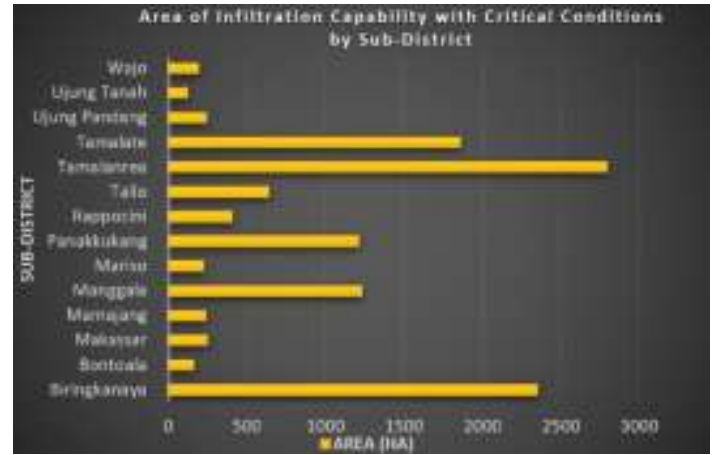

Figure 5. Land area of infiltration capability with critical conditions by sub-district

Soil compaction due to road construction and other urban development is one of the factors affecting the infiltration capability of a land (Cheremisinoff 1995). This is closely related to the analysis results which showed only settlement to have contributed $43 \%$ in the critical category followed by road with $18 \%$. Meanwhile, the infiltration capability associated with settlement land-use was discovered to have decreased or increased by $5 \%$ in 2020 and this is more critical than the land conditions in 2005 as indicated in figure 6 . 


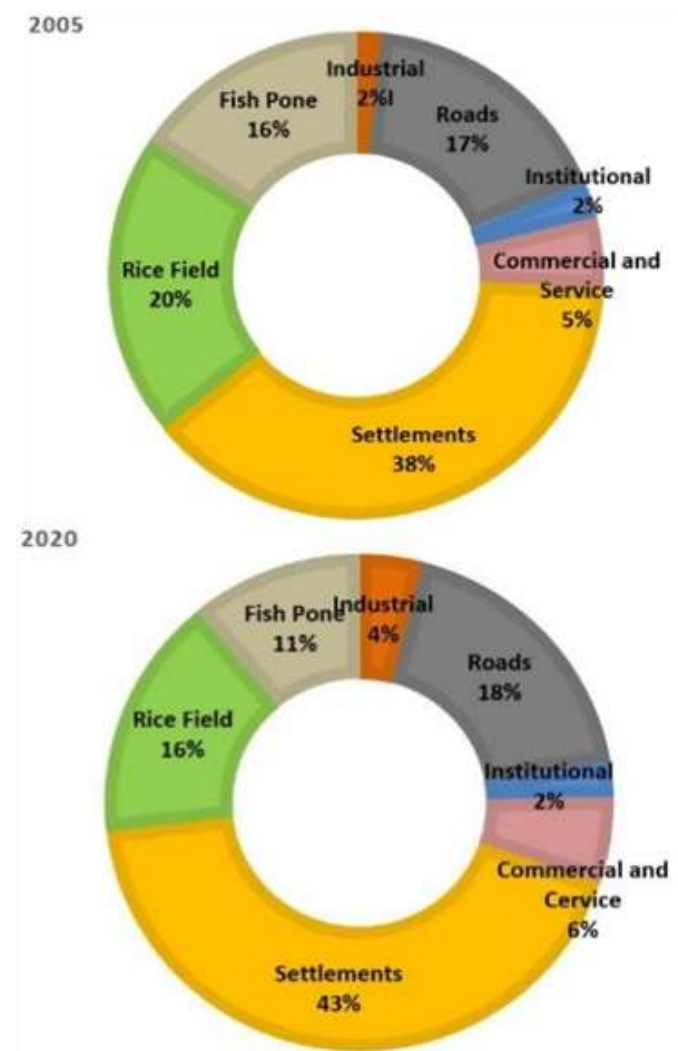

Figure 6. Percentage of critical infiltration capability by land-use in 2005 and 2020

The effect of surface runoff on inundation

Surface water or runoff is very influential in the mechanism of infiltration and occurrence of inundation. This was experimented by Walter et al. and Gao et al. in Dong et al. (2018) using three types of soil under three different infiltration conditions and the results showed the depths of raindrop penetration into the soil as well as the mixing zone was reduced. This means land-use change has a very strong effect on flooding or inundation due to the large-scale modification of the natural landscape through human activities (Rogger et al. 2017).

The overlay process was initiated using the contour data which stores information and classifies the height into five. Furthermore, the land use between 2005 and 2020 was overlaid to produce 61 ID's Polygons using equation (1) and two variables were multiplied to produce the volume/storage capacity. Meanwhile, further calculations showed the surface runoff discharge or rate was $2793.57 \mathrm{~m}^{3} /$ hour in 2005 and 3,085.67 $\mathrm{m}^{3} /$ hour in 2020. These values were later juxtaposed with the volume/capacity to determine the inundation distribution. The assumption was that the area is inundated when the runoff rate is greater than the volume or capacity but not when the runoff rate is lower or equal to the volume/capacity. The comparison results are, therefore, presented in figure 7. Moreover, the inundation area was also estimated from the runoff impact with or without a reduction in the infiltration process (maximum infiltration/saturation capability) based on maximum rainfall and poor drainage conditions. Figure 8 shows the distribution of inundation in existing conditions at several depths up to a height of 2 meters (Munsir 2020) and a total of 5 subdistricts were observed to be inundated with the worst recorded in Manggala and Biringkanaya (Faizin 2020). This, Therefore, makes it a routine for the Regional Disaster Management Agency to manage the aftermath of inundation or flooding in settlement areas of Makassar City with the focus on 3 sub-districts which include Manggala, Biringkanaya, and Tamalanrea (Tikupadang 2020). Furthermore, the inundation in the Tamalanrea area has been reported to be influenced by soil constituent elements present in the sub-district as indicated by the swampy areas. This is, therefore, one of the causes or indicators of critically degraded land (Sudia et al. 2018).

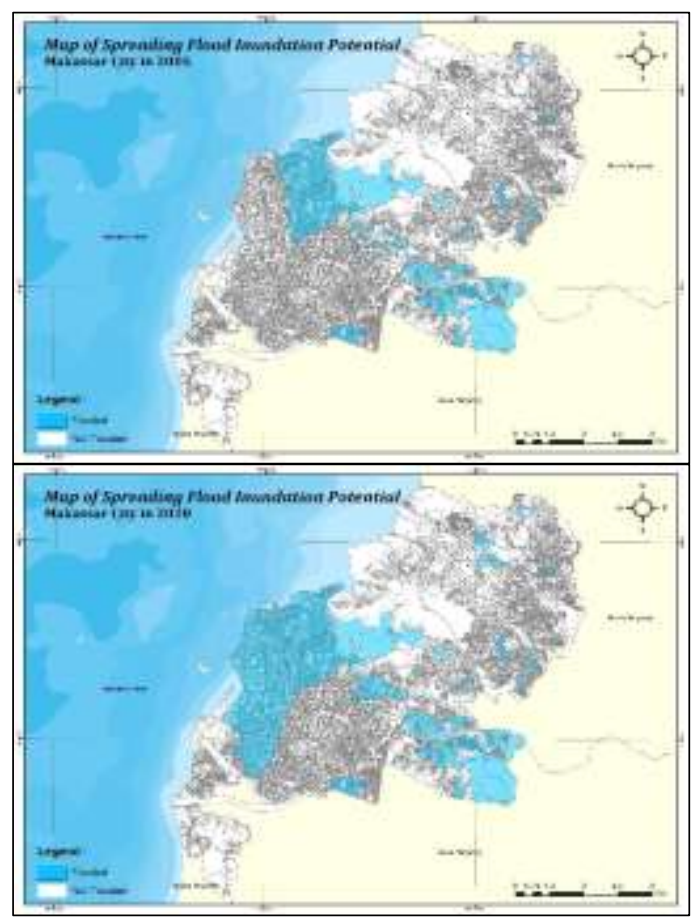

Figure 7. Distribution map of inundation potential on land use in 2005 and 2020 


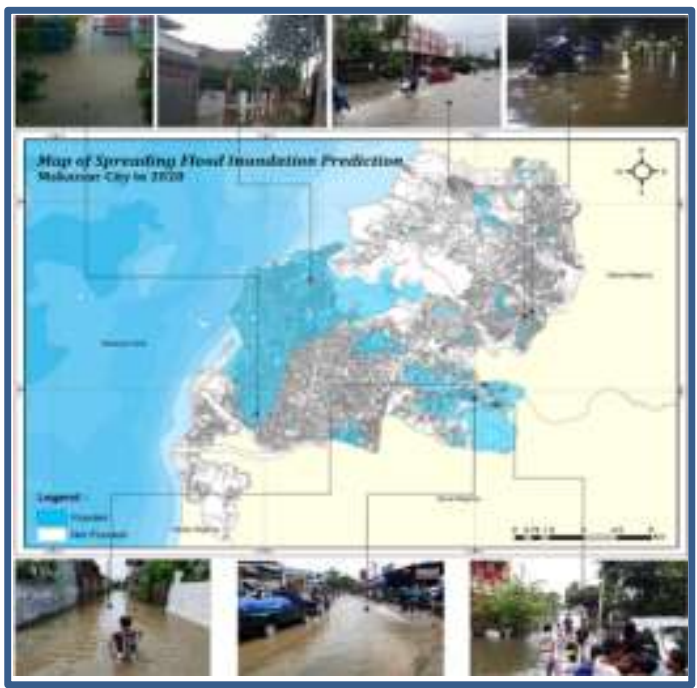

Figure 8. Photomapping the existing condition of inundation/floods in 2020

The classification of infiltration capability showed the places with critical conditions need to be prioritized for optimization. It is important to note that the average degraded land is in inundation areas with high runoff discharge/rates. The attributes of inundation and built-up land were overlaid with the land having critical infiltration capability and the results showed 8,574.4 ha of land need to be optimized as indicated in figure $9 \mathrm{a}$. This is necessary to reclaim the infiltration capability caused by the existing soil sealing conditions associated with road pavement and settlement which contributes the highest to land use at $24 \%$ and $56 \%$ respectively as showed in figure $9 \mathrm{~b}$.

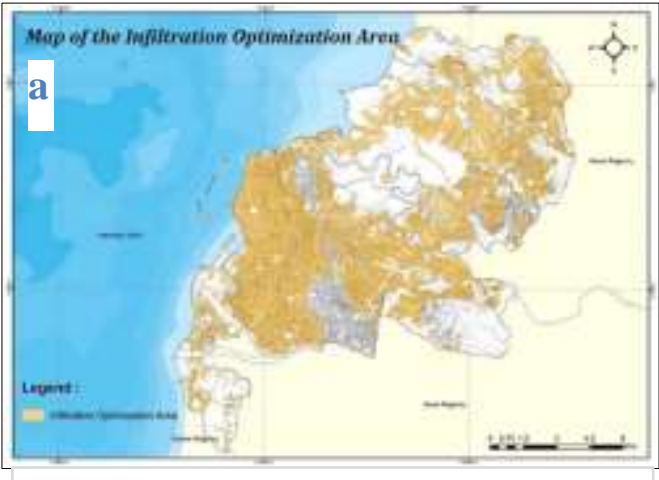

b

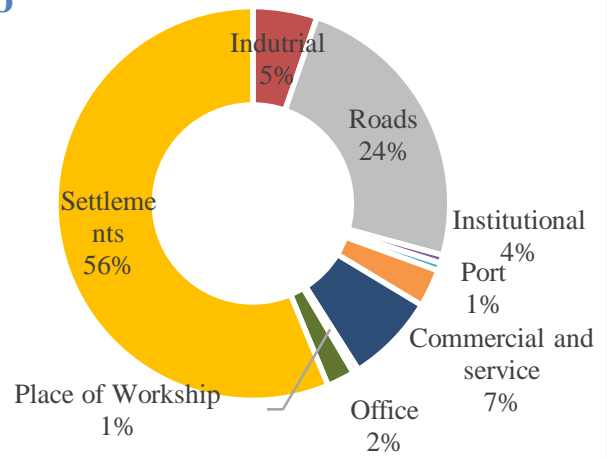

Figure 9. (a) Optimization for critical areas of infiltration capability based on built-up land (soil sealing) (b) the area of built-up land with critical infiltration capability based on land use in 2020

The analysis led to the proposal of certain alternative solutions and infiltration optimization methods in the urban area of Makassar towards achieving the idea of sustainable land-use efforts in the city. This involves the application of environmentally friendly building materials to revitalize the area. An example of this is the CirCuse concept (Preuß and Verbücheln 2013; Prokop and Birli 2013) which is a material cycle usually applied as a circular land-use management model. The process involves maintaining land storage capacity, reducing pavement (Adobati and Garda 2020), increasing green space, ensuring infrastructure is used efficiently, and avoiding unnecessary land grabbing in the future. This optimization method is highly recommended, especially on the land with minimal or critical land degradation or at points or land-use with low infiltration capability in the city as indicated in figure 9. This is in line with the findings of Styczen and Morgan (Jotisankasa, Mairaing, and Tansamrit 2014) that land with vegetation cover and soil surface which seeps into the roots usually 
have higher levels of permeability and infiltration and lower run-off.

\section{Conclusion}

The changes in land use and increased use of space as built-up land have a significant inverse effect on infiltration capability. This is evident in the critical status recorded to be $79.2 \%$ in 2005 and $82.8 \%$ in 2020 . These results indicate a decrease in infiltration capability and an increase in critical land conditions by $3.6 \%$ (617.72 ha) in the built-up area of the land. This is, however, not matched by the increase in water absorption capacity or land infiltration capability, thereby, causing a greater runoff rate and widespread flood inundation in 2020. Therefore, there is a need for infiltration optimization in Makassar City to increase the water storage capacity and soil absorption capacity due to the continuous increase in built-up land and soil sealing precisely in areas with critical infiltration capability. Moreover, the comprehensive plan to increase infiltration capability is highly important and needed urgently, especially in the places at a critical stage, in order to achieve sustainable land use.

\section{Acknowledgment}

The authors are grateful to all parties involved in the completion of this study. This research was funded by a research grant managed by the Community Service Agency (LP3M) of the Muhammadiyah University of Makassar with the contract No. 0011/KONTRPENL/PENGABD/IV/1441/2020, 16 May 2020.

\section{References}

Adobati, Fulvio, and Emanuele Garda. 2020. 'Soil Releasing as Key to Rethink Water Spaces in Urban Planning'. City, Territory and Architecture $\quad 7 \quad$ (1): 9 . https://doi.org/10.1186/s40410-020-00117-8.

Ardhiansyah, Nino, Dhyah Ayu Retno Widyastuti, and Elisabet Dita Septiari. 2019. 'Land Use Change in Kampung Prawirotaman Yogyakarta City as The Impact of The Existence of Commercial Area'. ARTEKS:
Jurnal Teknik Arsitektur 3 (2): 149-58. https://doi.org/10.30822/arteks.v3i2.66.

Arisandhy, Dana Rezky, Westi Susi Aysa, and Ihsan. 2013. 'Prediksi Genangan Banjir Menggunakan Metode Rasional USSCS 1973. Studi Kasus: Perumahan BTN Hamzy, BTN Antara, BTN Asal Mula, Kelurahan Tamalanrea Indah, Kota Makassar'. In Temu Ilmiah Iplbi, 7-12. Makassar: Jurusan Arsitektur, Fakultas Teknik, Universitas Hasanuddin.

https://temuilmiah.iplbi.or.id/wpcontent/uploads/2015/01/TI2013-07-p007-

012-Prediksi-Genangan-Banjir-

Menggunakan-Metode-Rasional-USSCS1973.pdf.

Artmann, Martina. 2014. 'Assessment of Soil Sealing Management Responses, Strategies, and Targets Toward Ecologically Sustainable Urban Land Use Management'. AMBIO 43 (4): 530-41. https://doi.org/10.1007/s13280014-0511-1.

Baskan, Oguz, Orhan Dengiz, and Atilla Gunturk. 2016. 'Effects of Toposequence and Land Use-Land Cover on the Spatial Distribution of Soil Properties'. Environmental Earth Sciences $\quad 75 \quad$ (5): 448. https://doi.org/10.1007/s12665-016-5301-6.

Chan, Faith Ka Shun, James A. Griffiths, David Higgitt, Shuyang Xu, Fangfang Zhu, Yu-Ting Tang, Yuyao Xu, and Colin R. Thorne. 2018. " "Sponge City" in China-A Breakthrough of Planning and Flood Risk Management in the Urban Context'. Land Use Policy 76 (July): 772-78. https://doi.org/10.1016/j.landusepol.2018.03. 005.

Cheremisinoff, N. P. 1995. Environmental Health \& Safety Management: A Guide for the Professional Hazards Manager. Westwood, New Jersey: Noyes Publishers.

Dong, Wencai, Chengpeng Cao, Xianbing Meng, Quanjiu Wang, and Qiang Fu. 2018. 'Experimental Studies on the Transfer of Dissolved Solutes from Soil into Surface Runoff on Loess Slopes in China'. Applied Water Science $8 \quad$ (6): 188. https://doi.org/10.1007/s13201-018-0832-5.

Faizin, Eko. 2020. 'Banjir Rendam 5 Kecamatan Dan 12 Kelurahan Di Makassar'. SuaraSulsel.Id. 2020. https://sulsel.suara.com/read/2020/12/20/170 
345/banjir-rendam-5-kecamatan-dan-12-

kelurahan-di-makassar?page=all.

Flury, Roman, Florian Gerber, Bernhard Schmid, and Reinhard Furrer. 2021. 'Identification of Dominant Features in Spatial Data'. Spatial Statistics $41 \quad$ (March): 100483. https://doi.org/10.1016/j.spasta.2020.100483.

Forth \& Van Dy. 2020. 'Table 6-1 Town of Fountain Prairie Existing Land Use and Acreage'. Town of Fountain Prairie Year 2020 Land Use Plan. 2020. http://www.co.columbia.wi.us/columbiacount y/Portals/26/LandUsePlan/ch6.pdf.

Gargouri-Ellouze, Emna, Saeid Eslamian, Kaveh Ostad-Ali-Askari, Rim Chérif, Maroua Bouteffeha, and Fairouz Slama. 2018. 'Infiltration'. In , 1-3. https://doi.org/10.1007/978-3-319-121277_169-1.

Hasibuan, Friska, Fermanto Lianto, Samsu Hendra Siwi, and Martinus Bambang Susetyarto. 2021. 'Utilization of Public Open Space in Kampung Deret Petogogan Jakarta'. ARTEKS: Jurnal Teknik Arsitektur 6 (2): 189-98.

https://doi.org/10.30822/arteks.v6i2.654.

Histanto, Enrico Nirwan, and Yohanes Karyadi Kusliansjah. 2018. 'Evaluation of Arragement and Use of Green Open Space in Cimai City's Rusunawa'. ARTEKS: Jurnal Teknik Arsitektur 2 (2): 99-112. https://doi.org/10.30822/arteks.v2i1.44.

Jotisankasa, A, W Mairaing, and S Tansamrit. 2014. 'Infiltration and Stability of Soil Slope with Vetiver Grass Subjected to Rainfall from Numerical Modeling'. In Unsaturated Soils: Research \& Applications, 1241-47. CRC Press. https://doi.org/10.1201/b17034-181.

Khare, Deepak, Diptendu Patra, Arun Mondal, and Sananda Kundu. 2017. 'Impact of Landuse/Land Cover Change on Run-off in the Catchment of a Hydro Power Project'. Applied Water Science 7 (2): 787-800. https://doi.org/10.1007/s13201-015-0292-0.

Lazaro, Timothy R. 1990. Urban Hydrology: A Multidisciplinary Perspective. Lanscaster, Pennsylvania: Technomic Publishing.

Manik, K. E. S. 2016. Pengelolaan Lingkungan Hidup. Jakarta: Prenadamedia Group.

Munsir, Ibnu. 2020. 'Banjir Setinggi 2 Meter Rendam Perumnas Antang Makassar, 774 Warga Mengungsi'. DetikNews. 2020. https://news.detik.com/berita/d5303445/banjir-setinggi-2-meter-rendam- perumnas-antang-makassar-774-wargamengungsi.

Patanduk, Johannes, Ardi Arsyad, and A. Rauf. 2014. 'Pengaruh Perubahan Tata Guna Lahan Terhadap Koefisien Limpasan (Run Off) Kota Makassar Berbasis SIG'. Jurnal Tugas Akhir. https://core.ac.uk/download/pdf/77619759.pd f.

Perring, Michael P., Pieter De Frenne, Lander Baeten, Sybryn L. Maes, Leen Depauw, Haben Blondeel, María M. Carón, and Kris Verheyen. 2016. 'Global Environmental Change Effects on Ecosystems: The Importance of Land-Use Legacies'. Global Change Biology 22 (4): 1361-71. https://doi.org/10.1111/gcb.13146.

Pouyat, Richard V., Deborah S. Page-Dumroese, Toral Patel-Weynand, and Linda H. Geiser, eds. 2020. Forest and Rangeland Soils of the United States Under Changing Conditions. Cham: Springer International Publishing. https://doi.org/10.1007/978-3-030-45216-2.

Praseyto, Sri Yulianto Joko, Bistok Hasiholan S., Kristoko Dwi Hartomo, Mila Paseleng, and Bayu Nuswantoro. 2013. 'Geographic Information System of Critical Level of Land Degradation (Critical Land) Based on AgroEcological Zone (AEZ) in Agricultural Areas with Recombination Method of Fuzzy Logic and Scoring'. International Journal of Computer Science Issues 10 (6): 217-21. https://www.ijcsi.org/papers/IJCSI-10-6-1217-221.pdf.

Preuß, Thomas, and Maic Verbücheln. 2013. Towards Circular Flow Land Use Management: The CircUse Compendium. Berlin: Berlin Deutsches Institut für Urbanistik.

Prokop, Gundula, and Barbara Birli. 2013. 'Circular Flow Land Use Management (CircUse)'. In Environmental Illustrations. Austria: Environmental Agency Austria.

Rogger, M., M. Agnoletti, A. Alaoui, J. C. Bathurst, G. Bodner, M. Borga, V. Chaplot, et al. 2017. 'Land Use Change Impacts on Floods at the Catchment Scale: Challenges and Opportunities for Future Research'. Water Resources Research 53 (7): 5209-19. https://doi.org/10.1002/2017WR020723.

Sudarmanto, Arif, Imam Buchori, and Sudarno. 2013. 'Analisis Kemampuan Infiltrasi Lahan Berdasarkan Kondisi Hidrometeorologis Dan Karakteristik Fisik DAS Pada Sub DAS Kreo Jawa Tengah'. In Optimasi Pengelolaan 
Sumberdaya Alam Dan Lingkungan Dalam Mewujudkan Pembangunan Berkelanjutan, 175:175-82. Semarang: Universitas Diponegoro. http://eprints.undip.ac.id/40664/.

Sudia, La Baco, Umar Ode Hasani, Kahirun, and Abdul Jalil. 2018. 'Analisis Tingkat Bahaya Erosi Dan Lahan Kritis Di Daerah Aliran Sungai Roraya Provinsi Sulawesi Tenggara'. $\begin{array}{llll}\text { Ecogreen } & 4 & \text { (1): } & 17-25 .\end{array}$ http://ojs.uho.ac.id/index.php/green/article/vi ew/4157.

Sun, Di, Hong Yang, Dexin Guan, Ming Yang, Jiabing Wu, Fenghui Yuan, Changjie Jin, Anzhi Wang, and Yushu Zhang. 2018. 'The Effects of Land Use Change on Soil Infiltration Capacity in China: A MetaAnalysis'. Science of The Total Environment 626 (June): 1394-1401. https://doi.org/10.1016/j.scitotenv.2018.01.10 4.

Syauqi, M. Barron, and Suprapto Dibyosaputro. 2017. 'Studi Pengaruh Perubahan Penggunaan Lahan Terhadap Perubahan Infiltrasi Dan Limpasan Permukaan Di Sebagian Wilayah Desa Maguwoharjo, Depok, Sleman, D. I. Yogyakarta'. Jurnal Bumi Indonesia 6 (4): 113.

http://lib.geo.ugm.ac.id/ojs/index.php/jbi/arti cle/view/894.

Tikupadang, Sahrul Manda. 2020. 'Banjir Makassar, Ratusan Warga Di 3 Kecamatan Masih Mengungsi'. CNN Indonesia. 2020. https://www.cnnindonesia.com/nasional/2020 1223003623-20-585441/banjir-makassar- ratusan-warga-di-3-kecamatan-masihmengungsi.

Tobias, Silvia, Franz Conen, Adrian Duss, Leonore M. Wenzel, Christine Buser, and Christine Alewell. 2018. 'Soil Sealing and Unsealing: State of the Art and Examples'. Land Degradation \& Development 29 (6): 2015-24. https://doi.org/10.1002/ldr.2919.

Tristan Grupp. 2020. 'Indonesia Focuses on Mechanisms That Support Sustainable Land Use and Forestation Projects'. Climate Scorecard. 2020. https://www.climatescorecard.org/2020/03/in donesia-focuses-on-mechanisms-thatsupport-sustainable-land-use-and-forestationprojects/.

\section{Author(s) contribution}

Sahabuddin Latif contribute to the research concepts preparation and literature reviews, data analysis, of article drafts preparation and validation.

Nurhikmah Paddiyatu contributed to the research concepts preparation, methodologies, investigations, data analysis, visualization, articles drafting and revisions.

Andi Yusri contribute to methodology, supervision, and validation.

Sumarni Baking contribute to methodology, supervision, and validation. 